\title{
Seismic hazard on West Bandung district using non-linear earthquake response analysis
}

\author{
Anggun Mayang Sari ${ }^{1,5^{*}}$, Afnindar Fakhrurrozi ${ }^{1}$, Arifan Jaya Syahbana ${ }^{1,2}$,Dwi Sarah $^{1}$, Bambang Setiadi ${ }^{1}$, Mudrik \\ Rahmawan Daryono ${ }^{1}$, Rabieahtul Abu Bakar ${ }^{3}$, and Jian Cheng Lee ${ }^{4,5}$ \\ ${ }^{1}$ Research Center for Geotechnology (P2G-LIPI), Indonesian Institute of Sciences, Bandung, Indonesia \\ ${ }^{2}$ Faculty of Civil and Environmental Engineering, Bandung Institute of Technology, Bandung, Indonesia \\ ${ }^{3}$ Razak Faculty of Technology and Informatics, University Technology Malaysia (UTM), Kuala Lumpur, Malaysia \\ ${ }^{4}$ Institute of Earth Science, Academia Sinica, Taipei, Taiwan \\ ${ }^{5}$ Integrated Research on Disaster Risk-International Centers of Excellence (IRDR-ICoE), Taipei, Taiwan
}

\begin{abstract}
West Bandung District is one of the government areas that grow rapidly in West Java. Here several infrastructures such as Highspeed Rail Development, Modern Residences, Tourist Attractions Area, and International Retail Company supply major contributions to economic development. Rapid construction in Bandung Basin caused the government to pay attention to risk factors, especially building structures. One of the natural hazards that must be considered is the presence of an active Lembang fault. Therefore, there is a need for a study that takes into account how the earthquake waves damaged the buildings. In this study, an analysis of the soil dynamics due to earthquake ground motion from bedrock was carried out. The analysis is carried out using the wave propagation method, which is a non-linear analysis of the soil response. The research was conducted at 12 points locations in West Bandung District. As the result, the location with the highest PGA surface value is in the Mekar Jaya area, while the lowest risk is found in the Cililin area. Furthermore, this study provides scientific information on seismic hazards to support government disaster risk reduction programs.
\end{abstract}

\section{Introduction}

West Bandung District grows rapidly in a few decades. As Greater Bandung is in the development stage towards a metropolitan city [1], several developments, both infrastructure and economic development, are being accelerated. The government gives full attention to development both physically and economically. One of the development aspects that need to be considered is the risk aspect due to natural hazards. Geologically, Bandung Basin is surrounded by several active fault sources such as the Lembang and Cimandiri faults $[2,4]$. The source of the subduction earthquake also affects the presence of people in the Bandung Basin.

Several studies related to seismic hazards in Bandung Basin have been carried out previously [5]. One of them is a study conducted by Sari et al [5]. The method used is Probability Seismic Hazard Analysis (PSHA) on a $500 \mathrm{~km}$ seismic source radius from a certain location in the Bandung basin. The results of the PSHA analysis are shown by the Peak Ground Acceleration at bedrock, where the area that has the highest PGA value is the West Bandung District, while the area that has the lowest value is the Bandung District (Fig. 1.).

To determine the seismic hazard that affects the building structure, it is necessary to calculate the surface
PGA value. The surface PGA value is then used as a seismic load for building calculations such as foundation loading and upper structure loading. To obtain the surface PGA value, earthquake waves propagate from the bedrock to the ground surface. This study analysed the surface PGA using the soil response method. The soil profile is based on the CPTu field investigations data. Here, CPTU 01 to 12 are located in the West Bandung District (Fig. 2.)

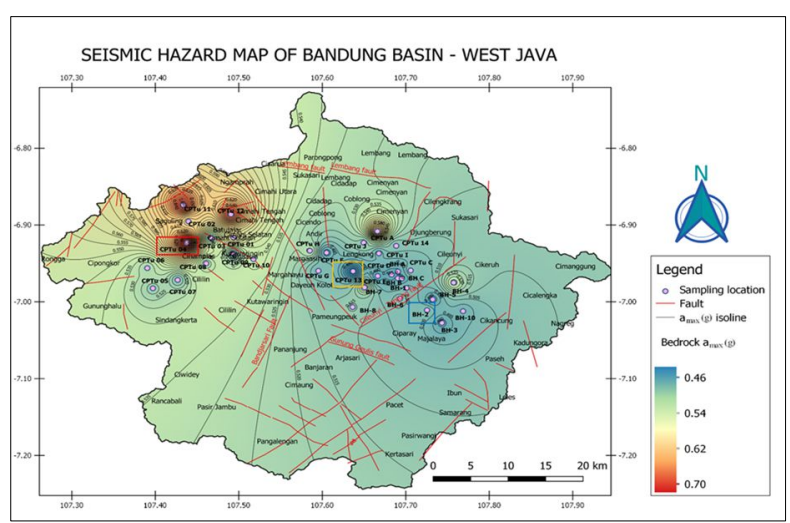

Fig. 1. Seismic Hazard Map on Bedrock located in the Bandung Basin [5].

\footnotetext{
* Corresponding author: anggunmayangsari@gmail.com
} 


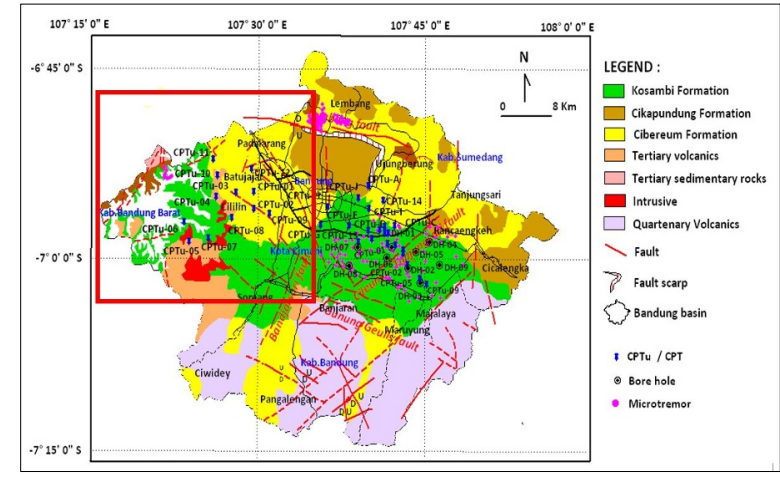

Fig. 2. Geological Map of Bandung Basin. The 12 point CPTu location in West Bandung District is marked with the red box.

\section{Methods}

Wave Propagation analysis can be defined as the seismic wave propagation from the bedrock to the earth's surface. Several studies on wave propagation have been carried out $[6,8]$. In this study, an analysis was carried out using the non-linear earthquake response analysis method. The analysis was performed using a computer program or software, namely NERA. NERA stands for Nonlinear Earthquake Response Analysis, non-linear 1-D modelling. It produces relative velocity, amplification, and stress-strain on the surface by calculating material models, including viscoelastic models, linear equivalents, and material models. These methods require ground motion in the bedrock as a motion modelling input. The equations used by NERA are shown in Fig. 3.

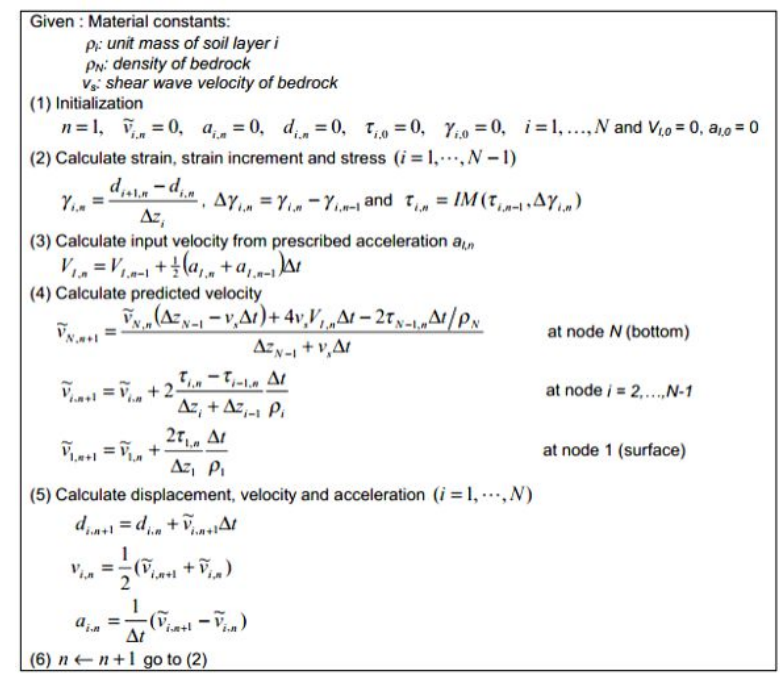

Fig. 3. The algorithms that were used in NERA ver.2001(Bardet and Tobitha, 2001).

The first stage in the NERA modelling is to identify earthquake ground motion on bedrock as input motion. The locations that already have a seismic record, i.e. accelerometer data or seismograph record on bedrock, can directly use the seismic motion data on programming. For the West Bandung District case, due to a lack of seismic record, the ground motion synthetic needs to be developed. This synthetic ground motion was created based on PSHA analysis using seismic sources at a 500 $\mathrm{km}$ radius from a certain point location in West Bandung District. The calculation resulted in a PGA value per second. This result was then used as the input motion in the NERA software (Fig. 4).

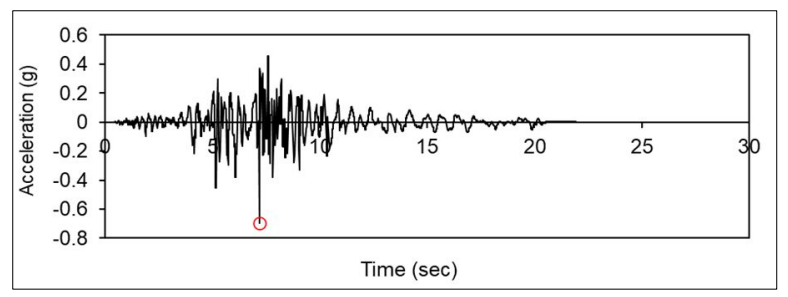

Fig. 4. Ground Motion Synthetic on CPTu 04 Location in West Bandung District.

The next step is to input soil profile data. The soil profiles data includes soil type, the thickness of the layer, total unit weight, and shear wave velocity. These data were obtained from the $\mathrm{CPTu}$ field investigation. The value of the shear modulus also needs to be considered. The shear modulus value is adjusted to the soil materials, which are silt, clay, and sand. The results of running data using NERA can be seen in Fig. 5.

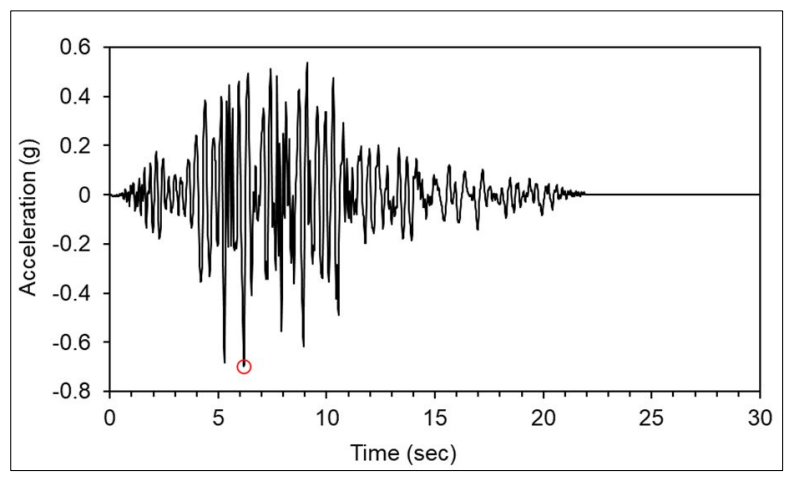

Fig. 5. Acceleration on CPTu 04 using NERA in West Bandung District.

The amplification factor is defined by the ratio between the seismic wave acceleration value in the bedrock and the acceleration value on the surface. The amplification factor equation in the $\mathrm{F}_{\mathrm{PGA}}$ based on ASCE / SEI 7.10 is given by:

$$
F_{P G A}=\frac{P G A_{S}}{P G A}
$$

Where PGA is the PGA value on the surface (g), PGA is the PGA value in the bedrock $(\mathrm{g})$, and $\mathrm{F}_{\mathrm{PGA}}$ is the amplification factor.

\section{Results and Discussion}

\subsection{Soil Layer Profiles}

Soil layers data were obtained from CPTu field investigations. Here, $12 \mathrm{CPTu}$ locations are distributed among several subdistricts in West Bandung District. The geological cross-sections were divided into three parts, 
which are cross-section A, cross-section B, and crosssection C. Cross-section A consists of CPTu-01, CPTu08, CPTu-07, and CPTu-05. The cross-section can be seen in Fig. 6. Soil layers stratigraphy from the surface is clay, organic soil, silt, and sand. Most of the soil profiles consist of clay and silt materials. The length of the cross-section is about $15 \mathrm{~km}$ and the depth of soil varies from $10 \mathrm{~m}$ until $25 \mathrm{~m}$.

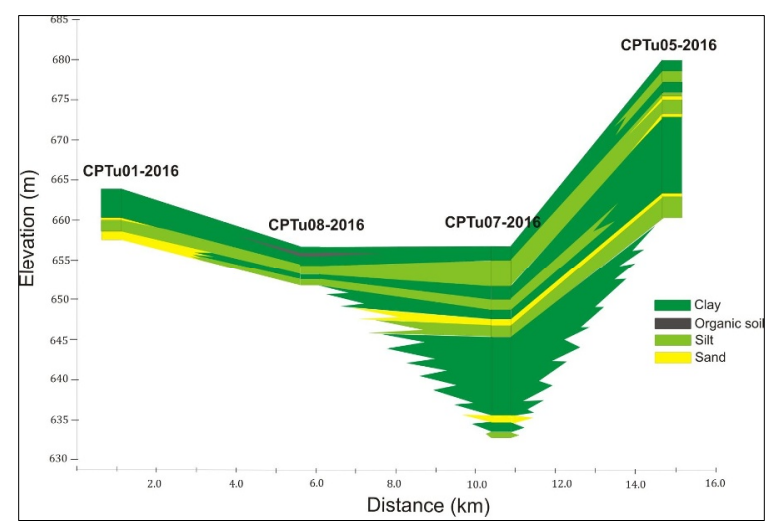

Fig. 6. Cross-section A on CPTu-01, CPTu-08, CPTu-07, and CPTu-05.

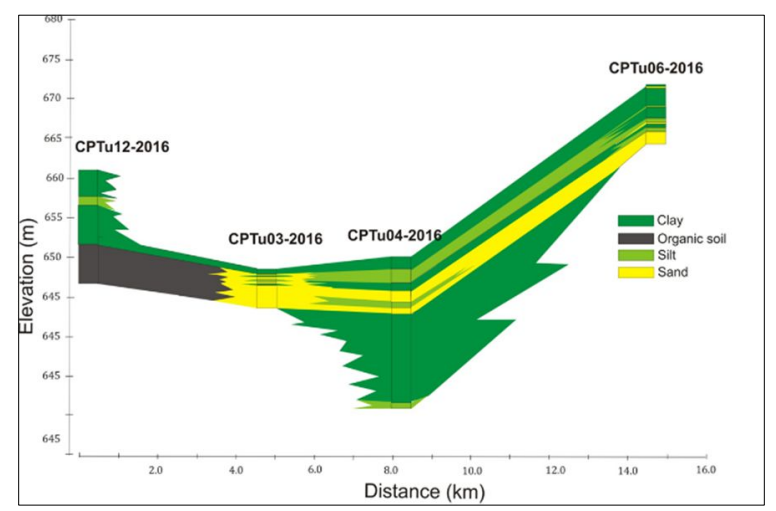

Fig. 7. Cross-section $\mathrm{B}$ on $\mathrm{CPTu}-12, \mathrm{CPTu}-03, \mathrm{CPTu}-04$, and CPTu-06.

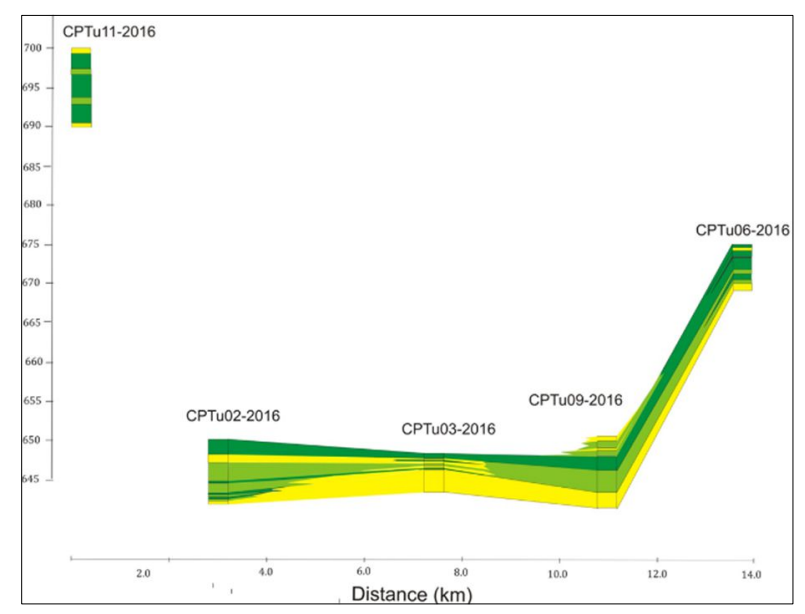

Fig. 8. Cross-section $\mathrm{C}$ on $\mathrm{CPTu}-11, \mathrm{CPTu}-02, \mathrm{CPTu}-03$, CPTu-09, and CPTu-06.

Cross-section B is located on CPTu-12, CPTu-03, CPTu-04, and CPTu-06. The distance of CPTu-12 to
CPTu-06 is around $15 \mathrm{~km}$, while the deep of the soil layer is $8 \mathrm{~m}$ until $19 \mathrm{~m}$. Clay material dominated the soil layer, while sand layers were found at $7 \mathrm{~m}$ thickness on $\mathrm{CPTu}-$ 03. CPTu-04 has some variation of soil profiles, consisting of clay, silt, and sand, while the clay material is also found $15 \mathrm{~m}$ above the hard soil layer. The organic soil is also found in CPTu-12, about $5 \mathrm{~m}$ thickness.

The length of cross-section $\mathrm{C}$ is $14 \mathrm{~km}$. This crosssection $\mathrm{C}$ consists of $\mathrm{CPTu}-11, \mathrm{CPTu}-02, \mathrm{CPTu}-03$, CPTu-09, and CPTu-06. The depth of layers varies from $5 \mathrm{~m}$ to $10 \mathrm{~m}$. Sand and silt materials are mostly found in CPTu-02, CPTu-03, and CPTu-9, while the clay layer is found in CPTu-11. The organic soil is also found in CPTu06.

\subsection{Peak Ground Acceleration on Surface}

Peak Ground Acceleration on Surface (PGAs) determined by using seismic wave propagation analysis. The earthquake waves propagated from the bedrock ground motion to the surface. Soil parameters; volumetric weight, stress-strain, groundwater level, damping modulus value, and shear wave velocity value, which are calculated in the propagation process. Here, NERA software is used to calculate non-linear earthquake soil response. One of the results can be seen in Fig. 9.

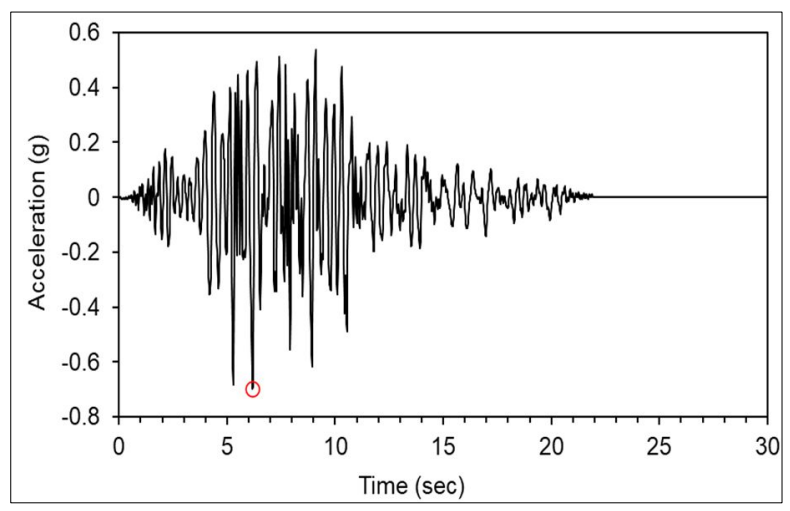

Fig. 9. Maximum PGA on the surface at CPTu 04 in West Bandung District.

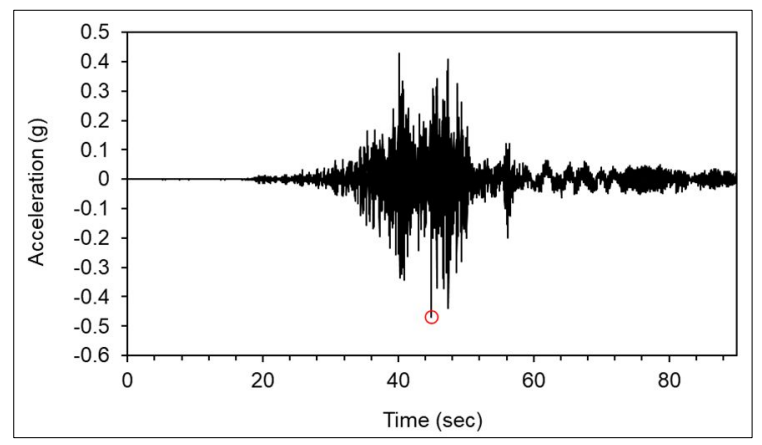

Fig. 10. Minimum PGA on the surface at CPTu 08 in West Bandung District.

The PGA surface in West Bandung District varies from $0.45 \mathrm{~g}$ to $0.70 \mathrm{~g}$. The highest value was found in CPTu-04, while the lowest value was found in CPTu-05. CPTu-04 is located in Mekar Jaya. Here, the soil profile 
is mostly dominated by clay materials. Sand and silt are laid down on the top of the clay material. The thickness of the clay layer is about $11.3 \mathrm{~m}$. This condition influenced the PGA value on the surface. As the wave propagation is very high in clay materials [6].

The minimum PGA value was determined on CPTu08, on the Cililin area (Fig. 10). Here, the soil profile consists of sand materials, about 5 meters in thickness. The clay soil was found at 2 meters depth from the surface. These conditions influence the soil response on the location, where the phase of the seismic wave travels from stiffer to softer materials leading to energy dissipation. Then, the wave propagation will be fully reflected [7].

\subsection{Amplification Factors}

From the PGA surface calculation and PGA bedrock analysis (sari et al, 2020), then the amplification factors are calculated using equation (2). The result of these amplification factors is shown in Table.1.

Table 1. Amplification Factors (FPGA)on West Bandung District

\begin{tabular}{|c|c|l|l|l|c|}
\hline $\begin{array}{c}\text { Locatio } \\
\mathbf{n}\end{array}$ & FPGA & Location & FPGA & Location & F PGA \\
\hline $\begin{array}{c}\text { CPTu- } \\
01\end{array}$ & 0.94 & CPTu-05 & 0.87 & CPTu-09 & 1.00 \\
\hline $\begin{array}{c}\text { CPTu- } \\
02\end{array}$ & 1.03 & CPTu-06 & 1.02 & CPTu-10 & 0.94 \\
\hline $\begin{array}{c}\text { CPTu- } \\
03\end{array}$ & 1.04 & CPTu-07 & 1.02 & CPTu-11 & 0.90 \\
\hline $\begin{array}{c}\text { CPTu- } \\
04\end{array}$ & 1.00 & CPTu-08 & 0.89 & CPTu-12 & 0.90 \\
\hline
\end{tabular}

The FPGA Site Class Coefficient table in ASCE/SEI 7.10 is used to determine the Validation of Amplification Factors (FPGA) value, which is described as follows:

Table 2. $F_{P G A}$ using Site Class Coefficient

\begin{tabular}{|c|c|c|c|c|c|}
\hline \multirow{2}{*}{$\begin{array}{c}\text { Site } \\
\text { Cla } \\
\text { ss }\end{array}$} & \multicolumn{5}{|c|}{$\begin{array}{l}\text { Mapped Maximum Considered Geometric Mean } \\
\text { (MCEG) Peak Ground Acceleration, PGA }\end{array}$} \\
\hline & $\begin{array}{l}\mathrm{PGA} \\
.1\end{array}$ & $\begin{array}{l}\text { PGA }=0 \\
.2\end{array}$ & $\begin{array}{c}\text { PGA }=0 \\
.3\end{array}$ & $\begin{array}{c}\text { PGA }=0 \\
.4\end{array}$ & $\begin{array}{l}\text { PGA } \\
\geq 0.5\end{array}$ \\
\hline A & 0.8 & 0.8 & 0.8 & 0.8 & 0.8 \\
\hline B & 1.0 & 1.0 & 1.0 & 1.0 & 1.0 \\
\hline $\mathrm{C}$ & 1.2 & 1.2 & 1.1 & 1.0 & 1.0 \\
\hline $\mathrm{D}$ & 1.6 & 1.4 & 1.2 & 1.1 & 1.0 \\
\hline $\mathrm{E}$ & 2.5 & 1.7 & 1.2 & 0.9 & 0.9 \\
\hline$F$ & \multicolumn{5}{|c|}{ See section 11.4 .7} \\
\hline
\end{tabular}

The Site Class type is defined by using CPTu correlation for each point location, while the PGA value is obtained from ground motion analysis. The $\mathrm{F}_{\mathrm{PGA}}$ value in table 1 is then compared to the F $_{\text {PGA }}$ of Site Class Coefficient value as shown as below:

Table 3. FPGA using NERA versus F $_{\mathrm{PGA}}$ using Site Class Coeff.

\begin{tabular}{|c|c|c|}
\hline Location & FPGA & $\begin{array}{c}\text { F PGA } \\
\text { (SC Coefficient) }\end{array}$ \\
\hline CPTu-01 & 0.94 & 0.90 \\
\hline CPTu-02 & 1.03 & 1.00 \\
\hline CPTu-03 & 1.04 & 1.00 \\
\hline CPTu-04 & 1.00 & 1.00 \\
\hline CPTu-05 & 0.87 & 0.90 \\
\hline CPTu-06 & 1.02 & 1.00 \\
\hline CPTu-07 & 1.02 & 1.00 \\
\hline CPTu-08 & 0.89 & 0.90 \\
\hline CPTu-09 & 1.00 & 1.00 \\
\hline CPTu-10 & 0.94 & 0.90 \\
\hline CPTu-11 & 0.90 & 0.90 \\
\hline CPTu-12 & 0.90 & 0.90 \\
\hline
\end{tabular}

Based on table 3, the amplification factor (FPGA) value is close to the FPGA value from the site class coefficient analysis. The results of surface PGA using soil CPTu data showed a more detailed result than PGA using site class coefficient. It means these results can be used for further calculation, such as seismic loads for structural building design.

\section{Conclusions}

To conclude, this study performed seismic hazards on the surface by analysing the soil response due to dynamic impact. The geological condition affected the value of surface acceleration. The Mekar Jaya area is located on Kosambi formation where this formation is composed of sedimentary rock. This condition caused the seismic wave to propagate high on these fine materials. In contrast, the Cililin area settled on the Cibereum formation. This formation is older than Kosambi Formation, which has more coarse materials than Kosambi form. These conditions produce the minimum value of wave propagation. Hence, the geological conditions are more or less influenced the acceleration calculation.

As previously determined, peak ground acceleration on clayey soil produced a high risk of ground shaking, whereas sandy soils tend to resist seismic waves. This condition needs special attention, especially the structure of the building, to minimize failures. Furthermore, this information is needed to support disaster mitigation programs, especially for natural disasters preparedness.

The authors would like to extend our appreciation to the Research Center for Geotechnology, the Indonesian Institute of Sciences for their full supports during the research. This work is based on the research supported wholly or in part by the Advanced Institute Seed Grant Program, which is implemented by the International Science Council Regional Office for Asia and the Pacific (ISC ROAP) and Integrated Research on Disaster 
Risk and the International Centre of Excellence Taipei (IRDR ICoE-Taipei). This work is also supported by Innovation System Research project funding (INSINAS 2021).

\section{References}

1. Government of the Republic of Indonesia, Presidential Regulation. Number 45 of 2018 concerning Urban Spatial Plans for the Bandung Basin. (2018)

2. M. R. Daryono, D. H. Natawidjaja, B. Sapiie, and P. Cummins, Tectonophysics 751, 180 (2019)

3. A. J. Syahbana, A. M. Sari, E. Soebowo, M. Irsyam, M. Asrurifak, and Hendriyawan, Proc. 20th Southeast Asian Geotech. Conf. 3rd AGSSEA Conf. Conjunction with 22th HATTI Annu. Sci. Meet. Thema Geotech. Chall. Mega Infrastructures (Indonesian Society for Geotechnical Engineering, Jakarta, 290-295 (2018)
4. A. M. Sari, A. Fakhrurrozi, and A. J. Syahbana, Proceedings of the 7th Mathematics, Science, and Computer Science Education International Seminar, MSCEIS 2019, 12 October 2019, Bandung, West Java, Indonesia (2020)

5. A. M. Sari and A. Fakhrurrozi, Ris. Geol. Dan Pertamb. 30, 215 (2020)

6. G. Seidalinov and M. Taiebat, in Comput. Methods Recent Adv. Geomech. (2015)

7. F. Gobuzi, L. I. Bengoa, and E. Va`no, Predict. Wave Propag. Soils Using Semi-Analytic Method Thesis, (2017)

8. J.P. Bardet and T. Tobita. Manual Program. The University of Southern California. Department of Civil Engineering. (2001)

9. W.D. Iwan. J. App. Mech., 34, 612-617 (1967)

10. Z. Mroz. J. Mech. Phys. Solids, 15, 163-175. (1967) 